\title{
Original Research \\ Drug-drug interactions and their predictors: Results from Indian elderly inpatients
}

\author{
Mandavi KASHYAP, Sanjay D'CRUZ, Atul SACHDEV, Pramil TIWARI. \\ Received (first version): 11-Jan-2013 Accepted: 3-Nov-2013
}

\begin{abstract}
*
Background: In view of the multiple co-morbidities, the elderly patients receiving drugs are prone to suffer with drug interactions since they receive a greater number of drugs.

Objective: The study was undertaken to determine the prevalence of drug interactions, as well as their predictors.

Method: The prescriptions of a total of 1510

inpatients were collected prospectively for 1.5 years from inpatients wards of public tertiary care teaching hospital. All the prescriptions were checked for drug interactions using the Micromedex ${ }^{\circledR}$ Drug-Reax database-2010 and Stockley's Drug Interactions. Regression analyses sought to determine predictors for the drug interaction.

Results: The patients, with the average age of 67.2 \pm 0.2 years, were prescribed an average of 9.15 \pm 0.03 medications. It was found that out of 1510 prescriptions of inpatients, $126(8.3 \%)$ prescriptions had one or more than one drug interaction. All the identified interactions were severe in nature.

The top most interacting drugs were acetylsalicylic acid and anticoagulant $(n=59)$. The second top most interacting drug combination was clopidogrel and proton pump inhibitors $(n=51)$. The most commonly involved drugs in interactions were $C$

(cardiovascular system) and A (alimentary tract and metabolism). Using multivariate binary logistic regression, multiple drugs (Odds Ratio $=4.5 ; 95 \%$ Confidence Interval: - 2.38 -9.47) and multiple diagnoses (Odds Ratio=2.6; 95\% Cl: $-1.40-5.57$ ) were found to be significant predictors for drug interaction.

Conclusion: The results of this study substantiate the occurrence of severe drug interactions among Indian elderly inpatients. In order to provide safer pharmaceutical care, the active involvement of clinical pharmacists is a potential option.
\end{abstract}

Keywords: Drug Interactions; Inpatients; India

\footnotetext{
Mandavi KASHYAP. PhD. Post Doctoral Fellow. Research Centre, Montreal University. Montreal (Canada). avi_mandu@yahoo.co.in

Sanjay D'CRUZ. MD, DM. Associate Professor,

Department of General Medicine, Government Medical College \& Hospital. Chandigarh (India).

Atul SACHDEV. MD, DM. Professor, Department of

General Medicine, Director Principal, Government Medical College \& Hospital. Chandigarh (India).

Pramil TIWARI. PhD. Professor \& Head, Department of Pharmacy Practice. National Institute of Pharmaceutical Education and Research, S.A.S. Nagar (India).
}

\section{INTERACCIONES MEDICAMENTOSAS Y \\ SUS PREDICTORES: RESULTADOS DE PACIENTES INDIOS HOSPITALIZADOS}

\section{RESUMEN}

Antecedentes: en función de las múltiples comorbilidades, los pacientes ancianos que reciben varios medicamentos son susceptibles de sufrir interacciones medicamentosas ya que reciben gran cantidad de medicamentos.

Objetivo: El estudio se realizó para determinar la prevalencia de interacciones medicamentosas, así como sus predictores.

Métodos: Se recogió prospectivamente la medicación total de 1510 pacientes hospitalizados de los servicios de internamiento de un hospital terciario universitario. Se revisaron todas las interacciones de los participantes usando Micromedex ${ }^{\circledR}$ Drug-Reax database-2010 y el Stockley's Drug Interactions. Los análisis de regresión trataron de determinar los predictores de la interacción medicamentosa.

Resultados: Los pacientes, con una media de 67,2 \pm 0.2 años, tenían prescritos de media $9.15 \pm 0.03$ medicamentos. De las 1510 prescripciones de pacientes hospitalizados, 126 (8,3\%) tenía una o más interacciones. Todas las interacciones identificadas eran de naturaleza grave. Los medicamentos más interactuante era el ácido acetilsalicílico y los anticoagulantes $(n=59)$. La segunda combinación interactuante más frecuente era clopidogrel y los inhibidores de la bomba de protones $(n=51)$. Los medicamentos más frecuentemente involucrados en interacciones eran del grupo C (aparato cardiovascular) y A (tracto alimentario y metabolismo). Usando la regresión logística binaria, se encontró que 'varios medicamentos' (Odds Ratio=4.5; Intervalo de Confianza 95\%: - 2.38 -9.47) y ¿varios diagnósticos' (Odds Ratio=2.6; 95\%CI: -1.40 5.57 ) eran predictores significativos de las interacciones medicamentosas.

Conclusión: Los resultados de este estudio demuestran la aparición de interacciones medicamentosas graves entre los pacientes indios hospitalizados. Para proporcionar una atención farmacéutica más segura, el empleo de farmacéuticos clínicos es una opción posible.

Palabras clave: Interacciones de medicamentos; Pacientes Internos; India 


\section{INTRODUCTION}

Ageing of the population is the most important demographic natural event facing most of the countries around the globe including India. By 2030 , the demographers expect that Indian population will touch 1.53 billion mark to surpass China. In 2040, it is expected that the elderly will constitute $14 \%$ of the total population (1.3 billion elderly population). ${ }^{1}$ By then, developing nations like India and China are expected to be home for over 1 billion people aged 65 years or more, accounting for $76 \%$ of the projected world total. The increase in population may be one of the most significant achievements of Indian society. At the same time, it has also posed a major health challenge that focuses on the ageing population segment.

The current literature confirms that elderly is known to be the largest consumers of medications. ${ }^{2}$ Moreover, this high rate drug consumption by elderly patients, age-related physiologic changes and an increased risk for disease associated with aging posed elderly at a high risk of drug interactions and increased prevalence of associated morbidity and mortality. Drug interactions (DIs) are most common and important type of adverse drug event because they are often predictable based on previous reports, clinical studies, and an understanding of pharmacologic principles. Some adverse drug events have life-threatening consequences and may expeditious the removal of popular medications from the marketplace. ${ }^{3}$ Such emphatic measures are probably justifiable because clinicians are often unaware of serious drug-drug interactions.

Little information is available about drug interactions in clinical practice among elderly in India and moreover most of the evidence is derived from case reports. In view of multiple co-morbidities, the elderly are at a special risk of drug interactions since they consume a greater number of drugs. It is also observed that drug interaction are the top most adverse events identified in elderly, therefore, it is important to study drug interactions under separate heading. Although it is meaningful to determine the number of drug interactions, it is also important to determine the severity of those interactions.

Therefore, the study was undertaken to determine the prevalence of drug interactions, as well as their predictors.

\section{METHODS}

The data of 1545 older inpatients was collected prospectively for 1.5 years from the medicine wards of a public teaching hospital. The inclusion criteria were age of 60 years and above, patients suffering from one or more disease conditions and receiving medications for their ailments. Data of 35 (of 1545 inpatients) with incomplete information were excluded. Therefore, the results of study are based on a total of 1510 inpatients. Patients were followed until discharge and the data form was updated daily. The study has been approved by independent ethics committee of Government Medical College and Hospital. The informed consent was obtained from each patient in their local languages.

All the diagnoses were coded according to International Classification of Disease ${ }^{4}$ (ICD-10) and drugs coded using Anatomical Therapeutic Chemical $^{5}$ (ATC) classification. All the prescriptions were checked for drug interactions using the Micromedex ${ }^{\circledR}$ Drug-Reax database- $2010^{6}$ and Stockley's drug Interactions. ${ }^{7}$ Only severe drug interactions based on the information of database were considered. Concurrent feedback was given to the physician for each identified drug interactions and confirmed by physicians, in order to validate the findings.

All the data was represented as average \pm SEM or percentages, as appropriate. In order to determine the predictors for the occurrence of drug interactions: age, number of medications, number of diagnoses and length of stay in hospital were regressed against the occurrence of drug interactions in both univariate and multivariate logistic regression analyses. Statistical analysis was performed using SPSS (version 17).

\section{RESULTS}

The results of the study based on total of 1510 inpatients which comprised of $63 \%$ of male. The average age of the inpatients was found to be 67.25 \pm 0.2 years. Out of 1510 patients, $62 \%$ of the patients were in the age group 60-69 years while $27.5 \%$ of the patients belonged to the age group 70 79 years and the rest of the patients were over 80 years of age $(n=159 ; 10.5 \%)$.

On an average, each patient had $2.63 \pm 0.03$ diagnoses. The patients were found to suffer from chronic co-morbidities. It was found that $57 \%$ of patients were suffering from 2 to 3 morbidities and $24 \%$ had between 4 and 6 co-morbid conditions. According to ICD-10, classification the most common co-morbidities were coronary artery disease with hypertension or diabetes, hypertension with liver disorder, diabetes with renal dysfunction and coronary artery disease with digestive disorder. The most commonly occurring disorder in the elderly inpatients was found to be the 'Diseases of circulatory system', $87 \%$. This was followed by 'Diseases of the digestive system' in the second rank (64\%) \& 'Endocrine, nutritional \& metabolic diseases' in the third place (39\%).

The average number of medications prescribed to patients was found to be $9.15 \pm 0.03$. Out of 1510 patients, $77 \%$ of the patients were prescribed more than 5 drugs. The average length of hospitalization was $7.40 \pm 0.11$ days. A $39 \%$ of the patients had the hospital stay up to 5 days while $41 \%$ of the patients stayed for $6-10$ days and $20 \%$ patients stayed for more than 10 days extending up to 43 days. The average number of discharge medications was 5.70 \pm 0.05 . Out of 1510 patients, $13.7 \%$ patients either expired or were referred to other hospital.

It was found that out of 1510 prescriptions of inpatients, 126 prescriptions had one or more than one drug interaction (8.3\%). However, the total 


\begin{tabular}{|l|l|c|}
\hline \multicolumn{1}{|c|}{ Table1: Prevalence of potential drug-drug interactions (n=151)-IPD } & $\begin{array}{c}\text { Number of } \\
\text { prescriptions }\end{array}$ \\
\hline & \multicolumn{1}{|c|}{ Potential adverse outcome } & 59 \\
\hline Anticoagulant therapy + Clopidogrel + Aspirin & Increased risk of bleeding & 51 \\
\hline Clopidogrel+PPIs & Increased risk of thrombosis & 10 \\
\hline Ramipril + Spironolactone & Hyperkalemia & 5 \\
\hline Furosemide + Ramipril & Postural hypotension & 4 \\
\hline Spironolactone + Digoxin & Digoxin toxicity & 4 \\
\hline Alprazolam + Digoxin & Digoxin toxicity (nausea, vomiting, arrhythmia) & 2 \\
\hline Diltiazem + Atorvastatin & Increased risk of rhabdomyolysis & 2 \\
\hline Heparin + Aspirin & Increased risk of bleeding & 2 \\
\hline Theophylline + Ciprofloxacin & Increased Theophylline toxicity & 2 \\
\hline Metronidazole + Warfarin & Increased risk of bleeding & 2 \\
\hline Warfarin + Pantoprazole & Increased INR and prothrombin time & 2 \\
\hline Insulin + Ciprofloxacin & Increased risk of hypoglycemia or hyperglycemia & 2 \\
\hline Diltiazem + Carvedilol & $\begin{array}{l}\text { Increased risk of hypotension, bradycardia, AV conduction } \\
\text { disturbance }\end{array}$ & 2 \\
\hline Hydrochlorthiazide + Ramipril & Postural hypotension & 1 \\
\hline Rifampicin + Isoniazid & Hepatotoxicity & 1 \\
\hline Diltiazem+metoprolol & $\begin{array}{l}\text { Increased risk of hypotension, bradycardia, AV conduction } \\
\text { disturbance }\end{array}$ & 1 \\
\hline Amoxicillin+warfarin & Increased risk of bleeding & 1 \\
\hline
\end{tabular}

number of Drug Interactions was 151. The drug interactions were classified based on the medication class involved. The most commonly involved drugs in interactions were $\mathrm{C}$ (Cardiovascular system) and A (Alimentary tract and metabolism). The detailed descriptions of all identified drug interactions are given in Table 1.

The associated predictors were also studied. Using multivariate binary logistic regression, it was found that the occurrence of DIs in different age group was not significantly different. A higher prevalence was detected in the elderly patients with multiple drugs (OR=4.5) and multiple diagnoses (OR=2.6). Gender and length of stay in the hospital was not significant predictors for drug interactions. The effect of variables on the drug interactions is depicted in Table 2.

\section{DISCUSSION}

Drug interactions are frequent among inpatients that were on multiple medications. The prevalence of major DIs was (8.3\%). The prevalence rate cannot be directly compared with those reported previously by other reports from different countries because of the differences in the study design and severity rating of drug interactions. There are few studies that can be directly compared with this study because these studies have also used Micromedex database to check the severity of interaction. These few studies had shown DIs in the range of 1.5-28\% of severe drug interactions in hospitalized elderly patients. ${ }^{8-11}$ Only one study has reported a very low rate $(1.5 \%) .^{8}$ The reason for higher rate of DIs in other studies could be due to the difference in the inclusion criteria of patient like patient from Intensive Care Unit, where usually chronically ill and patients with multiple complications requiring polypharmacy may pose at risk of DIs.

This study has identified drugs acting on cardiovascular system and alimentary tract as most prevalent drug classes involved in drug interactions. These finding coincide with the study performed by Manchon et al. ${ }^{12}$ and Dubova et al. ${ }^{13}$ which reported that drugs most often responsible for interactions were cardiovascular drugs and drugs acting on alimentary tract.

\begin{tabular}{|c|c|c|c|c|c|}
\hline \# & Variable & $\begin{array}{c}\text { Total } \\
\text { No. patients } \\
\end{array}$ & $\begin{array}{l}\text { Patients } \\
\text { with DDI }\end{array}$ & $\begin{array}{c}\text { Adjusted Odds ratio } \\
\text { (95\% confidence interval) }\end{array}$ & P-value \\
\hline 1 & All & 1510 & 126 & & \\
\hline 2 & $\begin{array}{r}\text { Age } \\
60-69 \mathrm{yrs} \\
70-79 \text { yrs } \\
80 \text { yrs or more } \\
\end{array}$ & $\begin{array}{l}937 \\
414 \\
159\end{array}$ & $\begin{array}{l}67 \\
29 \\
30\end{array}$ & $\begin{array}{c}1 \text { (reference) } \\
0.99(0.61-1.57) \\
3.04(1.84-4.94)\end{array}$ & $\begin{array}{l}0.009 \\
0.00\end{array}$ \\
\hline 3 & $\begin{array}{rr}\text { Sex } & \begin{array}{r}\text { Men } \\
\text { Women }\end{array} \\
\end{array}$ & $\begin{array}{l}943 \\
567\end{array}$ & $\begin{array}{l}84 \\
42 \\
\end{array}$ & $\begin{array}{c}1 \text { (reference) } \\
0.82(0.55-1.22)\end{array}$ & 0.30 \\
\hline 4 & $\begin{array}{r}\text { No. of medication } \\
\text { Less than } 6 \\
6-10 \\
11 \text { or more }\end{array}$ & $\begin{array}{l}340 \\
587 \\
583\end{array}$ & $\begin{array}{l}11 \\
36 \\
79\end{array}$ & $\begin{array}{c}1 \text { (reference ) } \\
1.9(0.94-4.14) \\
4.5(2.38-9.47)\end{array}$ & $\begin{array}{l}0.05 \\
0.00\end{array}$ \\
\hline 5 & $\begin{array}{r}\text { Length of stay } \\
\text { Less than } 10 \text { days } \\
10-19 \text { days } \\
20 \text { days or more }\end{array}$ & $\begin{array}{c}1162 \\
309 \\
39\end{array}$ & $\begin{array}{l}95 \\
28 \\
3\end{array}$ & $\begin{array}{c}1 \text { (reference) } \\
1.13(0.7-1.78) \\
1.07(0.23-3.25)\end{array}$ & $\begin{array}{l}0.61 \\
0.91\end{array}$ \\
\hline 6 & $\begin{array}{r}\text { Num. of Diagnosis } \\
\text { Single } \\
\text { Double } \\
\text { Multiple }\end{array}$ & $\begin{array}{l}292 \\
427 \\
791\end{array}$ & $\begin{array}{l}11 \\
38 \\
77\end{array}$ & $\begin{array}{c}1 \text { (reference) } \\
2.42(1.2-5.28) \\
2.66(1.40-5.57)\end{array}$ & $\begin{array}{l}0.007 \\
0.001\end{array}$ \\
\hline
\end{tabular}


The top most identified interacting drugs were aspirin or combination of aspirin \& Clopidogrel along with anticoagulant of high severity. It is well known that elderly patients are at high thromboembolic risk, but conditions contributing to higher hemorrhagic risk are also more prevalent in this population. ${ }^{14,15}$ The use of anticoagulant with aspirin or along with Clopidogrel prolongs the clotting time resulting in an increase potential for bleeding. ${ }^{14,15}$ The bleeding episodes were documented in the patients included in this study and remedial actions (like dose reduction or discontinuation of therapy) were taken by clinicians.

The second top most identified interacting drugs were combination of Clopidogrel and proton pump inhibitors (PPIs, except pantoprazole). Among patients receiving Clopidogrel and concomitant therapy with proton pump inhibitors other than pantoprazole was associated with a loss of the beneficial effects of Clopidogrel and an increased risk of re-infarction. Omeprazole has been shown to inhibit the antiplatelet activity of Clopidogrel by inhibiting CYP2C19. Competitive interference within the P450 pathway could conceivably lead to a reduced amount of Clopidogrel undergoing biotransformation to the active drug required to effect a change in platelet inhibition. ${ }^{16-18}$

The inference in regard to PPIs and Clopidogrel first arose from the combined use of Clopidogrel and omeprazole, although several other PPIs have subsequently been found to be associated with a smaller or insignificant attenuation of the Clopidogrel antiplatelet effect; these PPIs included pantoprazole, esomeprazole, and to a lesser degree lansoprazole. ${ }^{19-21}$ In contrast to above reported studies COGENT provides reassurance that the interaction might not be clinically significant. ${ }^{22}$ But it should be noted that this was a trial with a gastrointestinal focus and was stopped early because of the difference in $\mathrm{Gl}$ events. Although current data does not show causation of adverse outcomes with PPI use because the available data are conflicting, this topic is still controversial. Careful risk-benefit assessment is required before prescribing PPIs for individual patients receiving dual antiplatelet therapy. More evidence from randomized controlled trials is needed to clarify this drug interaction dilemma. ${ }^{23}$ It should be noted that $\mathrm{H} 2$ receptor blockers are not as effective as PPIs at preventing gastrointestinal ulcer in patients taking Clopidogrel, but are a reasonable alternative for those at low risk for gastrointestinal bleeding.

Using logistic regression, it was found that multiple drugs and multiple diagnoses were potential predictors for DIs. The potential for drug interactions increases as the number of medications prescribed increases. In this study, the number of DIs increased with an increase in the number of medications prescribed. This matches with results reported by other research groups, showing that patients exposed to polypharmacy were at a risk of harmful drug interaction. ${ }^{10,11}$ Advanced age, gender and length of stay in the hospital were not significant risk factors for drug interactions. It is not in concordance with other results which have shown age above 80 years $(n=159 ; 10.5 \%)$ as significant predictor associated with the occurrence of DIs. ${ }^{11}$

\section{CONCLUSIONS}

These results substantiate the occurrence of severe drug interactions among Indian elderly patients. In order to provide safer pharmaceutical care, the active involvement of clinical pharmacists is a potential option.

\section{CONFLICT OF INTEREST}

The authors have no financial conflicts of interest to disclose with respect to this work.

Funding: Sponsor's Role: This study was funded by the National Institute of Pharmaceutical Education and Research, S.A.S Nagar, India. The sponsor had no role in the design, methods, subject recruitment, data collection, analysis and preparation of the paper.

\section{References}

1. Kevin K, He W. U.S. Census Bureau, International Population Reports. P95/09-1. An Aging World: 2008. Washington, DC: U.S. Government Printing Office; 2009.

2. Mendes-Netto RS, Silva CQV, Oliveira Filho A, Rocha CE, Lyra DP Jr. Assessment of Drug Interactions in elderly patients of a family health care unit in Aracaju (Brazil): A pilot study. Afr J Pharm Pharmacol 2011;5(7):812-818.

3. Juurlink DN, Mamdani M, Kopp A, Laupacis A, Redelmeier DA. Drug drug interactions among elderly patients hospitalized for drug toxicity. JAMA. 2003;289(13):1652-1658.

4. International classification of disease, in: International Statistical Classification of Diseases and Related Health Problems 10th Revision. 2007 version.

5. WHO collaborating centre for drug statistic methodology. Anatomical Therapeutic Chemical (ATC) classification index with Defined Daily Dose. Geneva: WHO; 2003.

6. DRUG-REAX (Micromedex), version 2010: Thomson MICROMEDEX; Greenwood Village, Colorado.

7. Stockley IH editor. Stockley's Drug Interactions. 7th edition. London: Pharmaceutical Press; 2006.

8. Roughead EE, Kalisch LM, Barratt JD, Gilbert AL. Prevalence of potentially hazardous drug interactions amongst Australian veterans. Br J Clin Pharmacol. 2010;70(2):252-257. doi: 10.1111/j.1365-2125.2010.03694.x

9. Braga TB, Pfaffenbach G, Weiss DP, Barros MB, Bergsten-Mendes G. Point prevalence of drug prescriptions for elderly and non-elderly inpatients in a teaching hospital. Sao Paulo Med J. 2004;122(2):48-52.

10. Locatelli J. Drug interactions in hospitalized elderly patients. Einstein 2007;5(4):343-346. 
11. Bista D, Saha A, Mishra P, Palaian S, Shankar PR. Impact of educational intervention on the pattern and incidence of potential drug-drug interactions in Nepal. Pharm Pract (Granada). 2009;7(4):242-247.

12. Manchon ND, Bercoff E, Lemarchand P, Chassagne P, Senant J, Bourreille J. Incidence and severity of drug interactions in the elderly: a prospective study of 639 patients. Rev Med Interne. 1989;10(6):521-525.

13. Doubova SV, Reyes-Morales H, Torres-Arreola LP, Suárez-Ortega M. Potential drug-drug and drug-disease interactions in prescriptions for ambulatory patients over 50 years of age in family medicine clinics in Mexico City. BMC Health Serv Res. 2007;7:147.

14. Robert-Ebadi H, Le Gal G, Righini M. Use of anticoagulants in elderly patients: practical recommendations. Clin Interv Aging. 2009;4:165-177.

15. Bajorek B. A review of the safety of anticoagulants in older people using the medicines management pathway. Ther Adv Drug Saf. 2011;2(2):45-58.

16. Juurlink DN, Gomes T, Ko DT, Szmitko PE, Austin PC, Tu JV, Henry DA, Kopp A, Mamdani MM. A population-based study of the drug interaction between proton pump inhibitors and clopidogrel. CMAJ. 2009;180(7):713-718. doi: 10.1503/cmaj.082001

17. Lau WC, Gurbel PA. The drug-drug interaction between proton pump inhibitors and clopidogrel. CMAJ. 2009;180(7):699-700. doi: 10.1503/cmaj.090251

18. Allen MJ, McLean-Veysey P. Interaction between clopidogrel and proton pump inhibitors. CMAJ. 2009;180(12):12281229.

19. Siller-Matula JM, Spiel AO, Lang IM, Kreiner G, Christ G, Jilma B. Effects of pantoprazole and esomeprazole on platelet inhibition by clopidogrel. Am Heart J. 2009;157(1):148.e1-e5. doi: 10.1016/j.ahj.2008.09.017

20. Sibbing D, Morath T, Stegherr J, Braun S, Vogt W, Hadamitzky M, Schömig A, Kastrati A, von Beckerath N. Impact of proton pump inhibitors on the antiplatelet effects of clopidogrel. Thromb Haemost. 2009;101(4):714-719.

21. Small DS, Farid NA, Payne CD, Weerakkody GJ, Li YG, Brandt JT, Salazar DE, Winters KJ. Effects of the proton pump inhibitor lansoprazole on the pharmacokinetics and pharmacodynamics of prasugrel and clopidogrel. J Clin Pharmacol. 2008;48(4):475-484. doi: 10.1177/0091270008315310

22. Bhatt DL, Cryer BL, Contant CF, Cohen M, Lanas A, Schnitzer TJ, Shook TL, Lapuerta P, Goldsmith MA, Laine L, Scirica BM, Murphy SA, Cannon CP; COGENT Investigators. Clopidogrel with or without omeprazole in coronary artery disease. N Engl J Med. 2010;363(20):1909-1917. doi: 10.1056/NEJMoa1007964

23. Momary K, Cavallari LH. Clopidogrel and proton pump inhibitors: between a rock and a hard place. Pharmacotherapy. 2010;30(8):762-765. doi: 10.1592/phco.30.8.762 